\title{
Cultivation Research of Innovation-type Foreign Language Talents under the Regional Economic Development Background
}

\author{
Wantong Huang \\ School of Foreign Studies, Henan Agricultural University, Zhengzhou Henan, 450002, China
}

Keywords: Regional economic development, Innovation-type foreign language talents, Cultivation, problems.

\begin{abstract}
The regional economy is the product of rapid development of human economy and society, a reflection of economic globalization as well as the director to ask more and more requirements to talents and market. The current rapid regional economic development makes the quantity required of innovation-type foreign language talents increasing, as well as asking higher demand to quality of talents. During the regional economic development, innovation-type foreign language talents play more and more important roles, thus the urgency to cultivate innovation-type foreign language talents is prominent increasingly. This article tries to analytically investigate current situation of cultivation to innovation-type foreign language talents, find and solve problems from this, hope to offer some benefit to the further exploration of cultivation to innovation-type foreign language talents and meanwhile have some enlightenments to talent cultivation under the regional economic development background.
\end{abstract}

\section{Introduction}

With the coming of informatization, economic globalization becomes the inexorable trend of the current world development. As the product of economic globalization, regional economic development is the sign of continuous improvement and development of human society. Now the regional economy develops rapidly as well as our country's economy, and meanwhile it asks higher requirements to the standard of talent cultivation. This article aims at the cultivation research of innovation-type foreign language talents under the rapid regional economic development background from pattern to social need, trying to find some problems, make contributions to the regional economic development in our country and point out a useful way for cultivation of innovation-type foreign language talents.

\section{Requirement of regional economic development to innovation-type foreign language talents}

The regional economic development is gradually flourishing with the development of modern information technology. Taking the current regional economic development as an example, as well as the requirement of the central government to the regional economic development, it would find that such development of modern information technology as "internet +" etc. is a kind of promotion to the regional economic development. It is in not only the technology level but also idea level. "Internet +" is on behalf of the advanced idea and spirit with innovative development. Requirements of regional economic development to talents become more and more strict, reflecting to the skill and innovative sharing idea. The concept of "Five Development" once suggested by General Secretary Xi Jinping is to not only the enterprises and market, but also talents' comprehensive quality. Only if you could adapt to all requirements suggested by regional economy with new tendency can you better show your ability and contribute to the national economic and social development.

\section{Innovation-type foreign language talents should become the main force of main force}

Innovative talents are the impetus for industrial structure keep constant optimization and the first people to make contributions to the regional economic development. The requirements of regional economic development to innovative talents mainly are reflected in talents' skills and idea. And the 
most direct reflection is the strict handling to talent recruitment. The innovation-type foreign language talents are those highly-competent people combining both innovativeness and prominent foreign language ability. In many enterprises, especially with the frequent external exchange after the reform and opening-up, the requirement to innovation-type foreign language talents becomes bigger and bigger. At the same time, their status in these enterprises grows with each passing day and gradually becomes the main force of industrial structure, which is the certain event. Because of the external exchange and competition, in order to get contract and profit, it is imperative to make contact with foreigners. Nowadays, foreign language has become a compulsory course. But it needs professional education to perfectly combine innovativeness and foreign language.

\section{Innovativeness and practicalness become basic quality for talents to survive}

The primary characteristic of innovation-type foreign language talents is innovativeness, which seems as a common occurrence but not really easy. When working in enterprises, the reflection of innovativeness is whether having some unexpected but effective ways or not. It can be regarded as inspiration as well as ability. It would be much more relaxing and easier to work with innovative people. Innovation-type foreign language talents should be those people with powerful practical ability. Such necessary quality is also what the enterprises and employers ask their employees to possess. But during regional economic development, such talents are very few, which is caused by social ignorance to those talents. Innovativeness and practicalness become basic quality for talents to survive, which would also play the decisive role in regional economic development.

\section{Learnability and comprehensiveness become basic way for talents to keep a foothold}

Creativeness is not enough. The powerful learning ability is also the necessary requirement that enterprises ask to the creative foreign language talents. Different from those vocabularies or sentences learned in school, foreign language in enterprises is more tend to be business vocabulary. Thus they need to possess comprehensive knowledge to work on such job, which ask them to learn more, contact new things and learn new knowledge to handle all challenges in work. Only when they have constant learning ability, overcome their own weaknesses and turn themselves into talents with integrated development can they stand on the trend of regional economic and social development to occupy a tiny space.

\section{Training system in enterprises to innovation-type foreign language talents}

Requirements of enterprises to innovation-type foreign language talents are obvious to all. However, under the current background of regional economic development, requirements to innovation-type foreign language talents is still relatively short, which asks enterprises to make good measure to meet such challenges. Starting from training system to innovation-type foreign language talents in enterprises, this article would analyze the situation of cultivation and introduction ways to innovation-type foreign language talents in enterprises.

\section{Self cultivation, medium-term and long-term plans}

To most enterprises, requirements to innovation-type foreign language talents are mainly in external regional economic developments, or contact to foreign customers. To such shortage of talents, general enterprises would adopt such measure to introduce talents from high schools and make self cultivation mode aiming at enterprise business, which need a long-term planning and training program. The setting of self cultivation and medium-term and long-term planning in enterprises is a good solution to requirements of innovation-type foreign language talents. With the premise to follow talents willing, pertinence cultivation not only is a process to improve capacity for talents themselves but also has acceleration to external development in enterprises. From such aspect, under the overall background of regional economic development, on step of training system of innovation-type foreign language talents in enterprises is to introduce relevant talents for self cultivation and professional knowledge cultivation. 


\section{To introduce high-level innovation-type foreign language talents}

However, in most instances, demand of enterprises to innovation-type foreign language talents is mainly from engaging talents in other enterprises with fat salary which invisibly increase operating costs of enterprises. Self cultivation in enterprises is very difficult, especially within the enterprises. It should have innovation-type talents with corresponding experience to cultivate such talents. At the same time, after cultivating such talents, it would also face the pressure that other peers may come to poach and those talents cultivated may go job-hopping after one night. Thus introducing high-level innovation-type foreign language talents is the choice for most enterprises, which would not affect resource out leakage of enterprises, etc. nor a secret for other peers. But it would have many loopholes because introduced talents can not truly fill up market vacancy for innovation-type foreign language talents for a long time. It has no material drive to regional economic development and may cause talents monopoly. This is also an important problem in training system of innovation-type foreign language talents and needs attention from all sectors of society.

\section{To build cooperation system with other enterprises or schools}

Under the training system of innovation-type foreign language talents in enterprises, the most effective way is to sign oriented contract with colleges and universities or substituted post exercitation and practical protocol with academy, driving more students in foreign language specialty to enter into enterprises to study and have physical training. At the same time, it could meet the requirements of enterprises to innovation-type foreign language talents and remit business pressure. To most enterprises, not only innovation-type foreign language talents but also stylist, engineers, etc. are all accomplished by dual culture of schools and enterprises. Under this circumstance, internship could solve problems that not only students lack self ability but also enterprises have difficulty in recruiting and using work force. And the uppermost is to provide platform to students. If students could stay at the enterprises after graduation, solving not only such problem with difficulty to find relevant talents but also students' problem of employment to work out scholastic fear of attacks from behind. Nowadays, with the development of regional economy, it is very necessary to establish such cooperation system with other enterprises or schools.

\section{How to vigorously cultivate innovation-type foreign language talents}

\section{Government increases degree of support}

Cultivating a lot of innovation-type foreign language talents needs joint effort from all sectors of society, reflecting in not only enterprises' recruiting and using work force but also regional and national economic and social development. It asks government to lead, concentrate demands of all sectors of society and cultivate corresponding innovation-type foreign language talents. As superintendent office, government could also guarantee benefit in all directions, which is an effective way.

\section{To build cultivation mechanism with university-enterprise cooperation}

Building university-enterprise cooperation mechanism is a very good cultivation way to cultivate innovation-type foreign language talents mentioned above and could also form a good training system. Combining the theoretical knowledge learned in schools and practical knowledge learned in enterprises is a comprehensive promotion to talents comprehensiveness, practicalness and innovativeness. Talents need chances to practice and platform to show themselves. The substituted post exercitation in enterprises is a good chance, where foreign language talents could enter into enterprises to work on corresponding work. It could not only release demand pressure of enterprises to foreign language talents but also select talents in demand to cultivate. It could also increase employment geared to the needs of the job to schools, which is a choice making the best of both worlds. 


\section{To cultivate corresponding talents according to requirements of regional economic development}

aiming at regional economic development and to cultivate talents with different languages according to enterprises in different countries. It can not cultivate only English talents. Under the current social environment, there are relatively many English talents but little talents of other languages, which should be paid attention by all sectors of society and solved purposefully. Under the current background of "One Belt and One Road", reinforcing regional economic development and cultivating Arabic talents in Arab countries are imperative. Similarly, other countries should also be like this.

\section{To optimize structure, widen channel and cultivate highly-competent people}

It is not enough to teach only language competence and more important to cultivate talent quality. Primary task of innovation-type foreign language talents is inventiveness and meanwhile comprehensive qualities such as practical ability, learning ability, etc. are also very important. A comprehensive talent could adapt to the trend of regional economic development. Optimizing training mode and cultivation structure, broadening ways to cultivate talents and cultivating high-quality and comprehensive innovation-type foreign language talents are of great significance to regional economic development. At the same time, it can not to be neglected for our country to keep up with the times and accelerate economic and social development. Only when sticking to walk on this correct way can we perfectly solve the problem of innovation-type foreign language talents cultivation and have more confidence in challenging economic globalization.

\section{Conclusion}

Nowadays, with the rapid development of regional economy, innovation-type foreign language talents cultivation faces strict requirements and quantity demanded in market to such talents increases day by day. Under such situation, it is very necessary and urgent to fully know requirements of market and enterprises to innovation-type foreign language talents. At the same time, it is necessary to find problems during innovation-type foreign language talents cultivation process and solve them to adapt to regional economic development. Vigorously cultivating innovation-type foreign language talents should start from government, mobilize resource and power among schools, enterprises and market and make more efforts to the cultivation of talents innovation and practicability, the reform of training mode and mechanism. Only when knowing the demands of market and enterprises can we how to cultivate innovation-type foreign language talents matching to the demands of market and enterprises. Innovation-type foreign language talents cultivation is a long and arduous task, which ask cultivation units, employers and functional government departments to make joint effort, overcome all kinds of difficulties to really improve innovation-type foreign language talents cultivation and promote service ability of regional economic development.

\section{Acknowledgement}

Henan soft-science research project "Cultivation Research of Innovation-type Foreign Language Talents under the Regional Economic Development Background" (No. 132400411212)

\section{Reference}

[1] Ruan Jun, Zhu Liyun, Hebei Regional Economic Development and Innovation-type Foreign Language Talents Cultivation, Journal of Hebei Normal University (science of education edition), 2013 (06).

[2] Sun Guolin, Yang Li, On Cultivation of Innovation-type Foreign Language Talents under the Regional Economic Development Background, Market Modernization, 2007 (12). 
[3] Li Mengmeng, Coupling Effect Study of Henan Regional Economic Development and Innovation-type Foreign Language Universal Talents Cultivation, Journal of Huaihai Institute of Technology (humanistic and social science edition), 2012 (03).

[4] Zhao Huiming, Simple Analysis of Application of Innovation-type Foreign Language Talents during Heilongjiang Regional Economic Development, Journal of Changchun Jiao Yu Xue Yuan, 2014 (12).

[5] Liu Haiqing, Teaching and Training Mode Study of Innovation-type Foreign Language Talents with Changzhutan Region as An Example , Journal of Central South University of Forestry and Tec (social sciences edition), 2014 (06).

[6] Zhang Xinfeng, On Coupling Effect of Henan Regional Economic Development and Innovation-type Foreign Language Universal Talents Cultivation, Feitian, 2012 (05). 